\title{
ANALISIS PELAKSANAAN ONLINE SYSTEM PAJAK DAERAH DALAM RANGKA PENERIMAAN PAJAK HIBURAN DAN PAJAK RESTORAN PADA SUKU BADAN PAJAK DAN RETRIBUSI DAERAH KOTA ADMINISTRASI JAKART PUSAT TAHUN 2014- 2016
}

\author{
Sulistyowati ${ }^{1}$, Nurina Sabila ${ }^{2}$ \\ Sekolah Tinggi Ilmu Ekonomi Indonesia, Jakarta \\ sulis.stei@gmail.com ${ }^{1}$ \\ nurinsabil1409@gmail.com ${ }^{2}$
}

\begin{abstract}
Abstrak
Penelitian ini bertujuan untuk menganalisis Pelaksanaan Online System Pajak Daerah Dalam Rangka Penerimaan Pajak Hiburan dan Pajak Restoran Pada Suku Badan Pajak dan Retribusi Daerah Kota Administrasi Jakarta Pusat Tahun 2014-2016. Penelitian ini menggunakan jenis penelitian deskriptif dengan pendekatan kualitatif. Data yang digunakan dalam penelitian ini berupa data primer dan data sekunder. Teknik pengumpulan data yang digunakan adalah studi pustaka, observasi, wawancara dan dokumentasi. Hasil penelitian menyimpulkan bahwa (1) Pelaksanaan penerimaan Pajak Hiburan dan Pajak Restoran yang diterima melalui Online System Pajak Daerah, yaitu dimana Wajib Pajak dapat membayarkan tagihan pajaknya melalui CMS BRI, yang disediakan oleh Bank BRI. (2) Untuk persentase efektivitas penerimaan Pajak Hiburan tertinggi diraih pada tahun 2016 sebesar 63,35\% dan persentase terendah terjadi pada tahun 2015 sebesar 35,84\%. Untuk persentase efektivitas penerimaan Pajak Restoran tertinggi terjadi pada tahun 2014 sebesar 109,35\% dan persentase terendah terjadi pada tahun 2015 sebesar 92,63\%. (3) Hambatan-hambatan yang dihadapi dalam melaksanakan penerimaan Pajak Hiburan dan Pajak Restoran adalah masih kurangnya Tingkat Kepatuhan Wajib Pajak terhadap Tagihan Pajaknya dan terdapatnya Wajib Pajak yang masih kurang memahami Online System Pajak Daerah.
\end{abstract}

Kata Kunci : Pajak Hiburan, Pajak Restoran, Online System Pajak Daerah

\section{PENDAHULUAN}

Pada dasarnya dalam kehidupan sehari-hari masyarakat di suatu negara selalu berhubungan dengan Pajak. Karena pajak merupakan suatu pungutan iuran yang dipungut atau di peroleh dari masyarakat yang bersifat dapat dipaksakan sesuai dengan peraturan-peraturan yang telah berlaku. Pajak nantinya akan di serahkan dan di nikmati kembali oleh masyarakat melalui kas negara. Pajak merupakan sumber pendapatan terbesar di suatu Negara yang pada nantinya akan digunakan untuk pelaksanaan pemerintahan serta pembangunan suatu Negara, salah satunya di Indonesia.

Pengenaan pajak di Indonesia dapat dikelompokkan menjadi 2 bagian yaitu: Pajak Negara dan Pajak Daerah. Pajak negara yang sampai saat ini yang masih berlaku adalah Pajak Penghasilan (PPh), Pajak Pertambahan Nilai dan Pajak Penjualan Atas Barang Mewah (PPN \& PPn BM), Bea Materai, Pajak Bumi dan Bangunan (PBB), Bea Perolehan Hak atas Tanah dan Bangunan (BPHTB). Sedangkan Pajak Daerah dibagi menjadi 2 yaitu : Pajak Provinsi dan Pajak Kabupaten/Kota. Pajak provinsi terdiri dari Pajak Kendaraan Bermotor, Bea Balik Nama Kendaraan Bermotor, Pajak Bahan Bakar Kendaraan Bermotor, Pajak Air Permukaan dan Pajak 
Rokok. Pajak Kabupaten atau Kota terdiri dari Pajak Hotel, Pajak Restoran, Pajak Hiburan, Pajak Reklame, Pajak Penerangan Jalan, Pajak Mineral Bukan Logam dan Batuan, Pajak Parkir, Pajak Air Tanah, Pajak Sarang Burung Walet, Pajak Bumi dan Bangunan Perdesaan dan Perkotaan, Bea Perolehan Hak atas Tanah dan Bangunan. (Mardiasmo, 2016 : 13-15).

Pajak Daerah merupakan salah satu dari sekian banyaknya sumber Pendapatan Asli Daerah. Pajak Daerah ini nantinya harus di maksimalkan dalam pemungutan serta penerimaannya sehingga Pendapatan Daerah yang dihasilkan akan maksimal pula. Menurut Undang-Undang No.28 Tahun 2009 Pajak Daerah di Indonesia adalah iuran wajib yang dilakukan oleh orang pribadi atau badan kepada daerah tanpa imbalan langsung yang seimbang, yang dapat dipaksakan berdasarkan peraturan perundang-undangan yang berlaku, dan yang digunakan untuk membiayai penyelenggaraan pemerintah daerah dan pembangunan daerah.

Dalam memaksimalkan penerimaan Pendapatan Daerah DKI Jakarta, Pemerintah Daerah Jakarta membuat beberapa strategi dalam meningkatkan kesadaran Wajib Pajak (WP) untuk membayar pajaknya sesuai dengan jumlah dan tepat waktu. Salah satu strategi yang dibentuk adalah pembayaran dan penerimaan Pajak Daerah melalui Online System Pajak Daerah yang ada di DKI Jakarta. Selain itu manfaat yang menguntungkan dari pelaksanaan Online System Pajak Daerah ini yaitu dapat mengurangi kemacetan yang ada di Jakarta. Karena Wajib Pajak nantinya tidak perlu lagi datang ke Kantor Pajak untuk membayar pajaknya. Wajib Pajak hanya perlu membayar pajaknya melalui laptop, komputer ataupun Mobile Phone yang terhubung pada internet.

Online System Pajak Daerah sendiri baru diterapkan oleh Pemerintah Daerah DKI Jakarta pada tahun 2008 bekerjasama dengan PT. Finnet Indonesia, untuk Pajak Hotel, Pajak Restoran, Pajak Hiburan, dan Pajak Parkir. Pada tahun 2012 Dinas Pelayanan Pajak DKI Jakarta bekerja sama dengan Bank Rakyat Indonesia (BRI) membangun Online System untuk Pajak Hotel, Pajak Restoran, Pajak Hiburan, dan Pajak Parkir. Kemudian pada tahun 2015 Pemerintah Daerah DKI Jakarta membangun lagi pembayaran pajak melalui Online System untuk 4 jenis pajak yaitu, PKB, PBB-P2, Reklame dan Restoran. Dan rencananya pada tahun 2016 yang lalu, Pemerintah Daerah DKI Jakarta berencana akan mengembangkan Online System untuk dapat melayani seluruh jenis Pajak Daerah. (Pajak Online Masuk Direvisi Perda Pajak Tangsel: 2016)

Rumusan masalah dalam penelitian ini adalah: 1)Bagaimana Mekanisme Pelaksanaan Penerimaan Pajak Hiburan dan Pajak Restoran melalui Online System Pajak Daerah?; 2)Berapa besar tingkat efektivitas penerimaan Pajak Hiburan dan Pajak Restoran yang diterima melalui Online System Pajak Daerah?; 3)Apa Sajakah Hambatan dalam Pelaksanaan Penerimaan Pajak Hiburan dan Pajak Restoran melalui Online System Pajak Daerah?

Berdasarkan Rumusan Masalah yang telah diuraikan diatas, maka tujuan dilakukan penelitian ini adalah untuk: 1)Untuk mengetahui mekanisme pelaksanaan penerimaan Pajak Hiburan dan Pajak Restoran melalui Online System Pajak Daerah; 2)Untuk mengetahui besarnya tingkat efektivitas dari penerimaan Pajak Hiburan dan Pajak Restoran yang diterima melalui Online System Pajak Daerah; 3)Untuk mengetahui hambatan dalam pelaksanaan penerimaan Pajak Hiburan dan Pajak Restoran melalui Online System Pajak Daerah.

\section{KAJIAN LITERATUR}

\subsection{Landasan Teori}

\subsubsection{Pajak}

Sumarsan (2010:3-5) mengemukakan terdapat bermacam-macam batasan atau definisi tentang "pajak" yang dikemukakan oleh para ahli salah satunya adalah:

Menurut Prof. Dr. H. Rochmat Soemitro SH, pajak adalah iuran rakyat kepada Kas Negara berdasarkan undang-undang (yang dapat dipaksakan) dengan tiada mendapat jasa timbal (kontra 
prestasi) yang langsung dapat ditunjukkan dan yang digunakan untuk membayar pengeluaran umum. Definisi tersebut kemudian dikoreksinya yang berbunyi sebagai berikut: Pajak adalah peralihan kekayaan dari pihak rakyat kepada kas Negara untuk membiayai pengeluaran rutin dan surplusnya digunakan untuk public saving yang merupakan sumber utama untuk membiayai public investment.

Dari definisi yang diberikan terhadap pajak baik pengertian secara ekonomis (pajak sebagai pengalihan sumber dari sektor swasta ke sektor pemerintah) atau pengertian secara yuridis (pajak adalah iuran yang dapat dipaksakan) dapat ditarik kesimpulan tentang ciri-ciri yang terdapat pada pengertian pajak antara lain sebagai berikut:

1. Pajak Dipungut oleh negara baik oleh pemerintah pusat maupun pemerintah daerah berdasarkan atas undang-undang serta aturan pelaksanaannya.

2. Pemungutan pajak mengisyaratkan adanya alih dana (sumber daya) dari sektor swasta (wajib pajak membayar pajak) ke sektor negara (pemungut pajak/administrator pajak).

3. Pemungutan pajak diperuntukkan bagi keperluan pembiayaan umum pemerintah dalam rangka menjalankan fungsi pemerintahan, baik rutin maupun pembangunan.

4. Tidak dapat ditunjukkan adanya imbalan (kontraprestasi) individual oleh pemerintah terhadap pembayaran pajak yang dilakukan oleh para wajib pajak.

Selain fungsi budgeter (anggaran) yaitu fungsi mengisi Kas Negara/Anggaran Negara yang diperlukan untuk menutup pembiayaan penyelenggaraan pemerintahan, pajak juga berfungsi sebagai alat untuk mengatur atau melaksanakan kebijakan negara dalam lapangan ekonomi dan sosial (fungsi mengatur / regulatif).

\subsubsection{Pendapatan Asli Daerah}

Pengertian pendapatan asli daerah menurut Undang-Undang No.28 Tahun 2009 yaitu sumber keuangan daerah yang digali dari wilayah daerah yang bersangkutan yang terdiri dari hasil pajak daerah, hasil retribusi daerah, hasil pengelolaan kekayaan daerah yang dipisahkan dan lain-lain pendapatan asli daerah yang sah.

Sedangkan menurut Nurcholis (2007:182), pendapatan asli daerah adalah pendapatan yang diperoleh daerah dari penerimaan pajak daerah, retribusi daerah, laba perusahaan daerah, dan lain- lain yang sah.

Soedjamanto (1999:72) mengemukakan bahwa PAD merupakan potensi yang sangat kuat didalam meningkatkan taraf pendapatan dan kesejahteraan masyarakat yang diperoleh dari berbagai pencarian dan pengalian sumber-sumber dana daerah yang pengelolaannya dapat dilakukan oleh semua pihak yang ada didaerah, baik pemerintah, swasta, pengusaha dan lainnya.

Pada dasarnya, setiap pemerintah daerah selalu berupaya seoptimal mungkin untuk memperbaharui manajemen pengelolaan PAD meningkatkan PAD adalah cerminan pendapatan masyarakat suatu daerah. Selain itu, pemerintah daerah akan dianggap gagal jika hanya mengandalkan bantuan keuangan dari pemerintah pusat. Untuk itu perlu adanya rumusan strategi bagi pemerintah daerah dalam pengelolaan sumber-sumber pendapatan daerah. Pemerintah daerah harus lebih cerdas mengidentifikasi titik-titik yang berpotensi meningkatkan PAD. Meningkatnya pendapatan masyarakat jelas mempengaruhi pertumbuhan ekonomi dan kesejahteraan sekaligus berpengaruh pada peningkatan Pendapatan Asli Daerah. Peningkatan PAD tidak terlepas dari kemampuan pemerintah dalam membina masyarakat dan unsur swasta dalam mewujudkan berbagai bidang usaha, yang pada gilirannya berperan besar dalam pemasukkan di kas daerah 


\subsubsection{Pajak Daerah}

Mardiasmo (2016:14-15) berpendapat pengertian atau istilah yang terkait dengan Pajak Daerah antara lain:

1. Daerah Otonom, selanjutnya disebut daerah, adalah kesatuan masyarakat hukum yang mempunyai batas-batas wilayah yang berwenang mengatur dan mengurus urusan pemerintahan dan kepentingan masyarakat setempat menurut prakarsa sendiri berdasarkan aspirasi masyarakat dalam sistem Negara Kesatuan Republik Indonesia.

2. Pajak Daerah, yang selanjutnya disebut pajak, adalah kontribusi wajib kepada daerah yang terutang oleh orang pribadi atau badan yang bersifat memaksa berdasarkan UndangUndang, dengan tidak mendapatkan imbalan secara langsung dan digunakan untuk keperluan Daerah bagi sebesar-besarnya kemakmuran rakyat.

3. Badan, adalah sekumpulan orang dan/atau modal yang merupakan kesatuan, baik yang melakukan usaha maupun yang tidak melakukan usaha yang meliputi perseroan terbatas, perseroan komanditer, perseroan lainnya, Badan Usaha Milik Negara (BUMN), atau Badan Usaha Milik Daerah (BUMD), dengan nama dan dalam bentuk apapun, firma, kongsi, koperasi, dana pensiun, persekutuan, perkumpulan, yayasan, organisasi massa, organisasi sosial politik, atau organisasi lainnya, lembaga dan bentuk badan lainnya termasuk kontrak investasi kolektif dan bentuk usaha tetap.

4. Subjek Pajak, adalah orang pribadi atau badan yang dapat dikenakan Pajak.

5. Wajib Pajak, adalah orang pribadi atau Badan, meliputi pembayar pajak, pemotong pajak, dan pemungut pajak, yang mempunyai hak dan kewajiban perpajakan sesuai dengan ketentuan peraturan perundang-undangan perpajakan daerah.

Sedangkan Hartati (2015:393) menyatakan Pajak Daerah merupakan pajak yang dipungut oleh pemerintah daerah dan digunakan untuk kepentingan pemerintah daerah. Secara garis besar pendapatan yang dimiliki oleh setiap daerah yang masuk ke kas daerah, terutama adalah bagi daerah yang memiliki hak otonomi daerah.

\subsubsection{Pajak Hiburan}

Menurut Perda Nomor 16 Tahun 2010, Pajak Hiburan adalah pajak atas penyelenggaraan hiburan. Selain itu, Pajak Hiburan dapat pula diartikan sebagai pungutan daerah atas peyelenggaraan hiburan. Dalam pemungutan Pajak Hiburan terdapat beberapa terminologi tersebut antara lain:

1. Hiburan adalah semua jenis pertunjukan, permainan, permainan ketangkasan, dan atau keramaian dengan nama dan bentuk apa pun, yang ditonton atau dinikmati oleh setiap orang dengan dipungut bayaran, tidak termasuk penggunaan fasilitas untuk berolahraga.

2. Penyelenggaraan hiburan adalah orang pribadi atau badan yang bertindak baik untuk atas namanya sendiri atau untuk dan atas nama pihak lain yang menjadi tanggungannya dalam menyelenggarakan suatu hiburan.

3. Pembayaran adalah jumlah yang diterima atau seharusnya diterima dalam bentuk apa pun untuk harga pengganti yang diminta atau seharusnya diminta wajib pajak sebagai penukar atas pemakaian dan atau pembelian jasa hiburan serta fasilitas penunjangnya termasuk pula semua tambahan dengan nama apa pun juga yang dilakukan oleh wajib pajak yang berkaitan langsung dengan penyelenggaraan hiburan. Termasuk dalam pengertian pembayaran adalah jumlah yang diterima atau seharusnya diterima, termasuk yang akan diterima, antara lain pembayaran yang dilakukan tidak secara tunai.

4. Harga tanda masuk, yang masuk disingkat HTM, adalah nilai uang yang tercantum pada tanda masuk yang harus dibayar oleh penonton atau pengunjung. 


\subsubsection{Pajak Restoran}

Menurut Peraturan Daerah Provinsi DKI Jakarta Nomor 11 Tahun 2011 tentang Pajak Restoran, Restoran adalah fasilitas penyedia makan dan/ minuman yang dipungut bayaran, yang mencakup juga rumah makan, kafetaria, kantin, warung, bar, dan sejenisnya termasuk jasa boga/ katering.

Sedangkan definisi restoran adalah usaha yang menyediakan, menghidangkan, dan menjual makanan/minuman bagi umum ditempat usahanya bertempat di sebagian atau seluruh bangunan permanen dilengkapi dengan peralatan dan perlengkapan proses pembuatan, penyimpanan, dan penyajian (dan telah mendapatkan surat keputusan sebagai restoran dari instansi yang membinanya).

Samudra (2015:152) berpendapat Subjek Pajak adalah orang pribadi atau badan yang melakukan pembayaran atas pelayanan penjualan makanan dan minuman di restoran.

Wajib Pajak adalah pengusaha restoran termasuk di dalamnya pengusaha rumah makan, warung makan, kafe, bar, pedagang kaki lima, kolam pancing dan/atau usaha lain yang sejenis yang disertai fasilitas penyantapannya atau disantap di tempat lain. Pengusaha sebagai penanggung Pajak Restoran bertanggung jawab sepenuhnya untuk menyetor pajak yang seharusnya terutang.

Samudra (2015:152) dasar pengenaan pajak adalah jumlah pembayaran yang dilakukan kepada restoran termasuk di dalamnya rumah makan, warung makan, kafe, bar, pedagang kaki lima, kolam pancing dan/atau usaha lain yang sejenis yang disertai fasilitas penyantapannya atau disantap di tempat lain, yang disertai dengan fasilitas penyantapannya dan memberikan pelayanan di tempat dan di bawa pulang (take way).

\subsubsection{Online System Pajak Daerah}

Online System Pajak Daerah adalah salah satu strategi yang dilakukan oleh Pemerintah Daerah DKI Jakarta dalam memaksimalkan penerimaan Pajak Daerah di DKI Jakarta yang nantinya akan berpengaruh pada Pendapatan Asli Daerah DKI Jakarta. Sebagaimana yang diungkapkan dalam Peraturan Gubernur Provinsi DKI Jakarta Nomor 92 Tahun 2011 Tentang Pelaksanaan Online System Atas Pelaporan Data Transaksi Usaha Wajib Pajak Hotel, Pajak Restoran, Pajak Hiburan dan Pajak Parkir Pasal 4:

(1) Untuk efisien dan efektivitas pelaporan data transaksi pembayaran Pajak Daerah, Gubernur atau pejabat yang ditunjuk dalam hal ini Kepala Dinas berwenang menghubungkan perangkat dan sistem informasi Pajak Daerah yang dimiliki Dinas Dengan perangkat dan sistem informasi transaksi usaha pada Wajib Pajak Hotel, Wajib Pajak Pajak Restoran, Wajib Pajak Pajak Hiburan dan Wajib Pajak Pajak Parkir secara Online System.

(2) Perangkat dan sistem informasi transaksi usaha Wajib Pajak dalam bentuk apapun yang digunakan oleh Wajib Pajak sebagaimana dimaksud pada ayat (1), untuk mencatat/merekam/menginput atas setiap transaksi pembayaran Pajak Hotel, Pajak Restoran, Pajak Hiburan dan Pajak Parkir oleh masyarakat/subjek pajak dilaksanankan oleh Dinas melalui Online System Pajak Daerah.

\subsubsection{Efektivitas}

Menurut Kamus Besar Bahasa Indonesia, kata efektif mempunyai arti efek, pengaruh, akibat atau dapat membawa hasil. Jadi, efektivitas adalah keaktifan, daya guna, adanya kesesuaian dalam suatu kegiatan orang yang melaksanakan tugas dengan sasaran yang dituju. Efektivitas pada dasarnya menunjukkan pada taraf tercapainya hasil, sering atau senantiasa dikaitkan dengan pengertian efisien, meskipun sebenarnya ada perbedaan diantara keduanya. Efektivitas 
menekankan pada hasil yang dicapai, sedangkan efisiensi lebih melihat pada bagaiman cara mencapai hasil yang dicapai itu dengan membandingkan antara input dan outputnya (Siagaan,

2001: 24). Istilah efektivitas selalu dalam bentuk perbandingan dan tidak pernah digunakan untuk penilaian yang mempunyai pengertian absolute.

Efektivitas dalam hubungannya dengan optimalisasi peningkatan penerimaan Pajak Daerah diharapkan agar sistem dan prosedur pemungutan bisa berjalan dan berlangsung dengan baik, itu harus dilihat dari sistem yang digunakan serta prosedur pelaksanaan pemungutan juga jadwal pemungutan dan pengawasan harus ditetapkan secara teratur agar menghasilkan penerimaan pajak yang tinggi.

\section{Kerangka Konseptual Penelitian}

Secara sederhana Kerangka Konseptual Penelitian dalam penelitian ini adalah sebagai berikut:

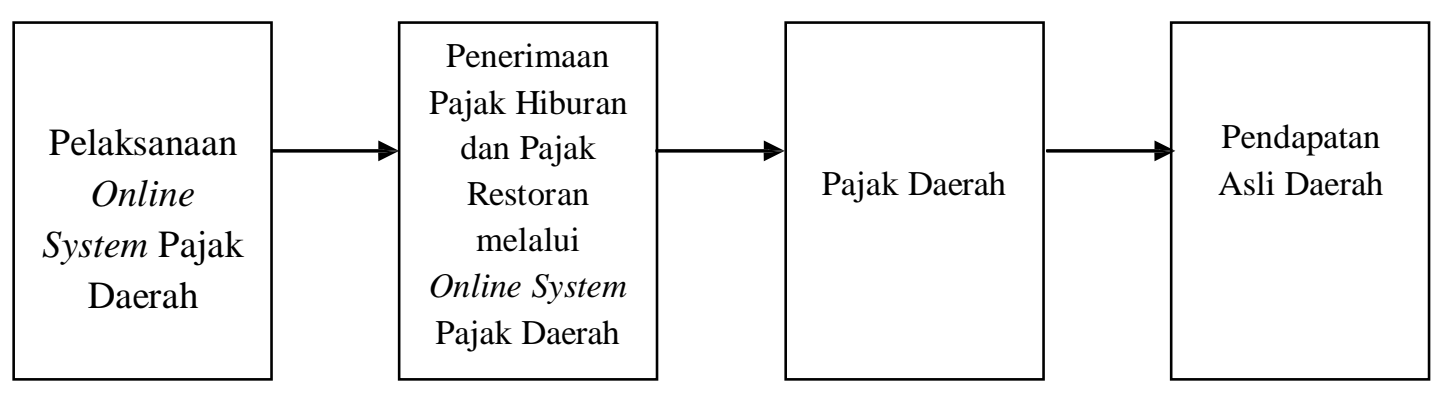

\section{Metode Penelitian}

\subsection{Strategi Penelitian}

Strategi yang peneliti gunakan dalam penelitian ini adalah deskriptif. Deskriptif adalah penelitian dengan cara mengolah data yang telah ada dan menggambarkan suatu objek dengan fakta yang sebenarnya, secara sistematis dari subjek dan objek tersebut diteliti secara akurat, tepat, dan sesuai kejadian yang sebenarnya. Peneliti menggunakan strategi deskriptif dikarenakan peneliti ingin menganalisis serta menjelaskan pelaksanaan Online System Pajak Daerah dalam melakukan penerimaan Pajak Hiburan dan Pajak Restoran yang merupakan salah satu bagian dari pajak daerah yang ada pada Provinsi DKI Jakarta, khususnya Jakarta Pusat.

\subsection{Data Penelitian}

Data Penelitian yang digunakan dalam penelitian ini adalah Data Primer dan Data Sekunder. Data Primer adalah sumber data yang diperoleh secara langsung dari sumber asli atau pihak pertama. Teknik wawancara digunakan peneliti untuk mendapatkan Data Primer tersebut. Data sekunder merupakan sumber data yang diperoleh peneliti secara tidak langsung melalui media perantara. Dokumentasi peneliti gunakan untuk mendapatkan data sekunder tersebut. Data sekunder yang digunakan berupa laporan tentang pelaksanaan Online System Pajak Daerah dan laporan mengenai penerimaan Pajak Hiburan dan Pajak Restoran yang diterima melalui Online System pada tahun 2014-2016 di Kota Administrasi Jakarta Pusat. 


\subsection{Teknik Pengumpulan Data dan Instrumen Pengumpulan Data}

\subsubsection{Teknik Pengumpulan Data}

Teknik Pengumpulan Data yang digunakan dalam penelitian ini adalah sebagai berikut:

1. Riset Kepustakaan (Library Research)

Yaitu penelitian yang dilakukan dalam rangka mendapatkan rangka mendapatkan teori yang relevan atau sesuai dengan masalah yang akan dibahas dalam penelitian ini. Adapun pengumpulan data diperoleh dari teori-teori buku peraturan perpajakan yang berlaku, teoriteori dari buku kuliah, literature serta data-data lainnya yang menyangkut dengan masalah yang diteliti.

2. Riset Lapangan (Field Research)

Yaitu penelitian yang dilakukan dengan cara mengumpulkan data-data mengenai pelaksanaan dan penerimaan pajak hiburan, dan pajak restoran melalui Online System Pajak Daerah, langsung ke tempat penelitian yang bersangkutan. Riset lapangan ini dilakukan melalui teknik:
a. Observasi
b. Wawancara
c. Dokumentasi

\subsubsection{Instrumen Pengumpulan Data}

Instrumen pengumpulan data adalah alat bantu yang dipilih dan digunakan oleh peneliti dalam kegiatannya mengumpulkan data, agar kegiatan tersebut menjadi sistematis dan mempermudah peneliti (Suharsimi, 2004). Instrumen yang digunakan antara lain:

a. Observasi, dalam metode ini instrumen yang digunakan berupa lembar pengamatan, yaitu dengan melakukan observasi partisipasif (observasi langsung) dengan cara melakukan riset selama 3 (tiga) bulan terhitung sejak Mei 2017 s/d Juli 2017 bulan di Kantor Badan Pajak dan Retribusi Daerah Kota Administrasi Jakarta Pusat. Untuk mendapatkan gambaran mengenai pelaksanaan serta penerimaan pajak hiburan dan pajak restoran melalui Online System Pajak Daerah di Jakarta Pusat.

b. Wawancara, dalam metode ini instrumen yang digunakan berupa pedoman wawancara semi terstruktur, instrumen ini dipilih untuk mendapatkan keterangan serta jawaban yang lengkap dan mendalam mengenai penerimaan pajak hiburan dan pajak restoran melalui Online System Pajak Daerah. Wawancara dilakukan terhadap Bapak Ali Hasan selaku Staff Sistem Informasi Manajemen Badan Pajak dan Retribusi Daerah Kota Administrasi Jakarta Pusat.

c. Dokumentasi, dalam metode ini instrumen yang digunakan berupa laporan mengenai pelaksanaan penerimaan pajak hiburan dan pajak restoran melalui Online System Pajak Daerah pada tahun 2014-2016, laporan target dan realisasi penerimaan pajak hiburan dan pajak restoran melalui Online System Pajak Daerah pada tahun 2014-2016.

\subsection{Metode Analisis Data}

Adapun teknik yang telah dilakukan oleh penulis adalah sebagai berikut :

1. Mengevaluasi mekanisme pelaksanaan penerimaan Pajak Hiburan dan Pajak Restoran melalui Online System Pajak Daerah

2. Membuat tabel target dan realisasi penerimaan Pajak Hiburan dan Pajak Restoran melalui Online System Pajak Daerah pada Suku Badan Pajak dan Retribusi Daerah Kota Administrasi Jakarta Pusat selama tahun 2014-2016. 
3. Menyusun tabel tingkat efektivitas pajak hiburan dan pajak restoran dengan menggunakan rumus (Halim dan Damayanti dalam Sambuaga, 2011)

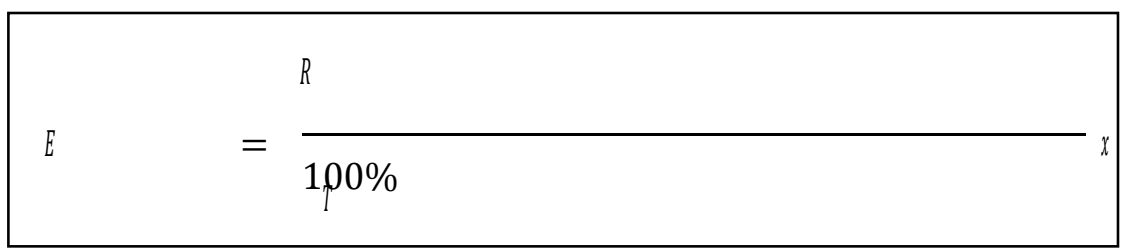

4. Menganalisa apa saja hambatan dalam melaksanakan penerimaan Pajak Hiburan dan Pajak Restoran melalui Online System Pajak Daerah.

\section{HASIL PENELITIAN DAN PEMBAHASAN}

\subsection{Deskriptif Data}

Tabel 4.1

Target dan Realisasi Penerimaan Pajak Hiburan

\begin{tabular}{|c|c|c|}
\hline Tahun & Target & Realisasi \\
\hline 2014 & Rp. 139.470 .000 .000 & Rp. 85.047.331.651 \\
\hline 2015 & Rp. 362.543 .000 .000 & Rp. 129.946.045.924 \\
\hline 2016 & Rp. 253.786.000.000 & Rp. 160.772.959.395 \\
\hline Sumber: Suku Badan Pajak dan Retribusi Daerah Prov. DKIJakarta
\end{tabular}

Dari tabel diatas dapat dilihat bahwa target penerimaan Pajak Hiburan yang diterima melalui Online System Pajak Daerah Dapat dilihat jika pada tahun 2014 target yang sudah ditetapkan oleh Pemerintah tidak tercapai atau tidak terealisasikan. Pada tahun 2015 target yang sudah ditetapkan oleh Pemerintah masih belum bisa tercapai. Pada tahun 2016 pun realisasi yang diterima belum bisa mencapai target yang telah ditetapkan.

\section{Tabel 4.2}

Target dan Realisasi Penerimaan Pajak Restoran

\begin{tabular}{|c|c|c|}
\hline Tahun & Target & Realisasi \\
\hline 2014 & Rp. 408.222.000.000 & Rp. 446.399.844.965 \\
\hline 2015 & Rp. 549.622.190.023 & Rp. 509.115.514.559 \\
\hline 2016 & Rp. 553.443.000.000 & Rp. 576.225.208.958 \\
\hline
\end{tabular}

Bisa dilihat pada tabel diatas, dimana pada tahun 2014 target penerimaan Pajak Restoran yang diterima melalui Online System Pajak Daerah telah tercapai dan terealisasikan. Untuk tahun 2015, Pemerintah memutuskan untuk menaikkan target penerimaan Pajak Restoran yang diterima melalui Online System Pajak Daerah. Namun dapat dilihat jika target yang telah ditetapkan oleh Pemerintah tidak mencapai target pada tahun ini. Pada tahun 2016 dapat dilihat jika target pada tahun ini dapat tercapai dan terealisasikan. 


\subsection{Pembahasan}

\subsubsection{Mekanisme Pelaksanaan Penerimaan Pajak Hiburan dan Pajak Restoran melalui Online System Pajak Daerah}

Seiring dengan perkembangan jaman, Pemerintah daerah DKI Jakarta membuat strategi baru dalam melakukan penerimaan Pajak Daerah. Pemerintah Daerah berfikir, mengapa tidak memanfaatkan perkembangan teknologi yang semakin hari semakin canggih untuk memudahkan Wajib Pajak dalam melaporkan dan membayarkan Pajak Daerahnya. Maka dari itu Perda DKI Jakarta melakukan penerimaan Pajak Daerah melalui Online System Pajak Daerah. Akan tetapi, Pemerintah Dearah DKI Jakarta tetap melakukan penerimaan Pajak Daerah melalui sistem manual walaupun nantinya sistem ini akan ditutup dan berfokus pada sistem Online.

Persamaan dari sistem manual dan sistem Online penerimaan Pajak daerah ini yaitu keduanya sama-sama menggunakan sistem pemungutan Self Assesment, dimana Wajib Pajak melaporkan, menghitung, dan membayarkan sendiri tagihan pajaknya. Adapun perbedaan dari kedua sistem ini yaitu pada sistem manual Wajib Pajak harus datang ke BPRD untuk membayarkann pajaknya. Sedangkan pada sistem Online Wajip Pajak hanya perlu melakukan Autodebet pada CMS BRI. Perbedaan kedua yaitu pada sistem manual mewajibkan si Wajib Pajak untuk melaporkan SSPD dan SPTPD ke Badan Pajak dan Retribusi Daerah. Sedangkan untuk sistem Online, Wajib Pajak bersangkutan hanya perlu mendownload e-SSPD dan e-SPTPD yang telah disediakan oleh CMS BRI.

Penerapan Online System Pajak Daerah pada Pemda DKI Jakarta bukanlah kali pertama yang diterapkan. Berdasarkan Pergub Nomor 22 tahun 2006 tentang "Pelaksanaan Sistem Online atas Data Transaksi Pembayaran Pajak Hiburan, Pajak Hotel, dan Pajak Restoran" dan Intruksi Gubernur Provinsi DKI Jakarta Nomor 182 Tahun 2008 tentang "Koordinasi Sistem Online atas Data Transaksi Pembayaran Pajak Hiburan, Pajak Hotel, dan Pajak Restoran melalui Proses Perizinan" Online System tahap pertama dilaksanakan pada tahun 2008. Pada saat itu Pemda DKI Jakarta bekerja sama dengan PT. Finnet untuk melakukan penerimaan pembayaran Pajak Daerah melalui Sistem Online.

Proses penerimaan Pajak Hiburan dan Pajak Restoran melalui Online System Pajak Daerah ini dilakukan untuk mengurangi tindak kriminal yang seringkali terjadi di DKI Jakarta dan juga mengurangi tingkat kebocoran pajak yang terjadi dikalangan Wajib Pajak dan Petugas Pajak. Apabila penerimaan dilakukan melalui sistem online, hanya dapat diketahui oleh Wajib Pajak yang bersangkutan dengan petugas Pajak yang ditunjuk oleh BPRD.

Berdasarkan hasil wawancara dengan Bapak Ali Hasan selaku staff seksi Sistem Informasi Manajemen, beliau mengungkapkan kedepannya makin besar kontribusi dari masyarakat, terutama Wajib Pajak untuk menggunakan Online System Pajak Daerah. Sehingga dapat tercapainya segala target dan tujuan yang telah dibuat oleh Pemda DKI Jakarta.

\subsubsection{Tingkat Efektivitas Penerimaan Pajak Hiburan dan Pajak Restoran melalui Online System Pajak Daerah di Provinsi DKI Jakarta}

Tabel 4.4

Efektivitas Pajak Hiburan Tahun 2014-2016

\begin{tabular}{|c|c|c|c|c|}
\hline Tẳhun & Target & Realisasi & $\%$ & Ket \\
\hline mo14 & Rp. 139.470.000.000 & Rp. 85.047.331.651 & 60,98 & Kurang Efektif \\
\hline 2015 & Rp. 362.543.000.000 & Rp. 129.946.045.924 & 35,84 & Tidak Efektif \\
\hline $\begin{array}{l}3016 \\
u\end{array}$ & Rp. 253.786.000.000 & Rp. 160.772.959.395 & 63,35 & Kurang efektif \\
\hline \multicolumn{3}{|c|}{ Rata-rata } & 53,39 & Tidak Efektif \\
\hline
\end{tabular}

Badan Pajak dan Retribusi Daerah Prov. DKI Jakarta 
Bisa dilihat pada tabel diatas jika penerimaan Pajak Hiburan yang diterima melalui Online System Pajak Daerah pada tahun 2014-2016 dapat dikatakan tidak efektif. Bahkan pada tahun 2015 tingkat efektivitas penerimaan Pajak Hiburan dikatakan tidak efektif, karena persentase yang didapat dibawah $60 \%$ yaitu 35,84\%. Persentase penerimaan Pajak Hiburan tertinggi terjadi pada tahun 2016 dengan hasil 63,35\% namun itu juga masih dikatakan kurang efektif untuk suatu tingkat efektivitas.

Tabel 4.5

Efektivitas Pajak Restoran Tahun 2014-2016

\begin{tabular}{|c|c|c|c|c|}
\hline Tahun & Target & Realisasi & $\%$ & Ket \\
\hline 2014 & Rp. 408.222.000.000 & Rp. 446.399.844.965 & 109,35 & Sangat Efektif \\
\hline 2015 & Rp. 549.622.190.023 & Rp. 509.115.514.559 & 92,63 & Efektif \\
\hline 2016 & Rp. 553.443.000.000 & Rp. 576.225.208.958 & 104,12 & Sangat Efektif \\
\hline \multicolumn{3}{|c|}{ Rata-rata } & 102,03 & Sangat Efektif \\
\hline
\end{tabular}

Sumber : Suku Badan Pajak dan Retribusi Daerah Prov. DKI Jakarta

Berdasarkan tabel diatas dapat dilihat jika tingkat efektivitas penerimaan Pajak Restoran melalui Online System Pajak Daerah mengalami kenaikan maupun penurunan pada setiap tahunnya. Namun berbeda dengan penerimaan Pajak Hiburan yang titik terendahnya pada angka $35,84 \%$, pada penerimaan Pajak Restoran tingkat efektivitas terendah terjadi pada tahun 2015 yaitu 92,63\% atau bisa dikatakan Efektif. Sedangkan persentase tertinggi terjadi pada tahun 2014 sebesar 109,35 dalam artian sangat efektif. Rata-rata efektivitas pada penerimaan Pajak Restoran yaitu 102,03 dikatakan sangat efektif, berbanding terbalik dengan penerimaan Pajak Hiburan yang rataratanya tidak efektif.

\subsubsection{Hambatan-Hambatan Dalam Pelaksanaan Penerimaan Pajak Hiburan dan Pajak Restoran Melalui Online System Pajak Daerah}

Dalam melaksanakan penerimaan Pajak Hiburan dan Pajak Restoran melalui Online System Pajak daerah, Pemda DKI Jakarta selalu memberikan kinerja yang optimal pada setiap tahunnya. Hal ini dilakukan agar penerimaan Pajak Hiburan dan Pajak Restoran selalu mengalami peningkatan, baik yang diterima secara manual maupun yang diterima secara Online. Berdasarkan hasil wawancara peneliti dengan Bapak Ali Hasan selaku staff seksi Sistem Informasi Manajemen, beliau mengungkapkan ada beberapa hambatan yang dihadapi Suku Badan Pajak dan Retribusi Daerah (BPRD) dalam melaksanakan penerimaan Pajak Hiburan dan Pajak Restoran melalui Online System Pajak daerah, yaitu:

\section{Masih kurangnya Tingkat Kepatuhan Wajib Pajak}

Dalam melaksanakan penerimaan melalui Online System Pajak Daerah, Suku Badan Pajak dan Retribusi Daerah (BPRD) menggunakan sistem pemungutan Self Assesment. Dimana Wajib Pajak melaporkan, menghitung, dan membayar sendiri tagihan pajak daerahnya, terutama dalam bidang Pajak Hiburan dan Pajak Restoran. Tentu ini merupakan suatu hambatan, karena nantinya Wajib Pajak dapat tidak melaporkan usaha dan pajaknya, dapat memanipulasi tagihan pajaknya, dan tidak membayarkan tagihan pajaknya. Hal tersebut tentu akan membuat penerimaan Pajak Hiburan dan Pajak Restoran menurun, dan berdampak pada turunnya penerimaan Pajak Daerah di Provinsi DKI Jakarta.

\section{Terdapat Wajib Pajak yang masih kurang memahami Online System Pajak Daerah}

Pelaksanaan Online System Pajak Daerah di Provinsi DKI Jakarta selama ini tidak 
terlepas dari dukungan Teknologi informasi (TI) yang semakin hari semakin canggih. Online System merupakan suatu penerapan dari teknologi informasi. Di Jakarta hampir semua Wajib Pajak menggunakan teknologi informasi dalam kehidupan sehari-hari mereka. Namun tidak sedikit dari Wajib Pajak yang terkadang masih kesulitan dalam melaporkan dan membayarkan pajaknya melalui Online System, terutama dalam menggunakan perangkat online yang bersangkutan. Terlebih lagi jika mereka tidak mempunyai petugas ataupun karyawan Teknologi Informasi (TI), tentu hal tersebut termasuk ke dalam hambatan penerimaan Pajak Hiburan dan Pajak Restoran, karena nantinya Wajib Pajak merasa terbebani dengan sistem online tersebut, dan membatalkan untuk melaporkan serta membayarkan tagihan pajaknya.

\section{SIMPULAN DAN SARAN}

\subsection{Simpulan}

Berdasarkan hasil penelitian yang dilakukan oleh peneliti pada Suku Badan Pajak dan Retribusi Daerah Kota Administrasi Jakarta Pusat, maka dapat ditarik simpulan sebagai berikut:

1. Pelaksanaan penerimaan Pajak Hiburan dan Pajak Restoran melalui Online System Pajak Daerah khususnya yang ada di DKI Jakarta sudah diterapkan sesuai dengan Peraturan yang telah dibuat oleh Pemerintah. Dimana Wajib Pajak dapat membayarkan tagihan pajaknya melalui CMS BRI, yang disediakan oleh Bank BRI.

2. Pada analisis tingkat efektivitas yang telah peneliti hitung pada Bab IV, hasil dari perhitungan tersebut menunjukkan bahwa penerimaan Pajak Hiburan melalui Online System Pajak Daerah tahun 2014-2016 memiliki rata-rata 53,39\% yang berarti Tidak Efektif. Sedangkan pada penerimaan Pajak Restoran melalui Online System Pajak Daerah tahun 2014-2016 memiliki rata-rata 102,03\% yang berarti Sangat Efektif.

3. Hambatan-hambatan yang dihadapi dalam pelaksanaan penerimaan Pajak Hiburan dan Pajak Restoran melalui Online System Pajak Daerah yaitu masih kurangnya tingkat kepatuhan Wajib Pajak dalam melaporkan dan membayarkan pajaknya. Tentu hal tersebut nantinya dapat menghambat penerimaan yang akan diterima oleh pemerintah. Hambatan lain yang dihadapi oleh pemerintah adalah terdapatnya Wajib Pajak yang masih kurang memahami Online System Pajak Daerah. Hal tersebut juga dapat mengakibatkan turunnya penerimaan yang ada.

\subsection{Saran}

Berdasarkan simpulan yang ada diatas mengenai pelaksanaan penerimaan Pajak Hiburan dan Pajak Restoran melalui Online System Pajka Daerah pada Suku Badan Pajak dan Retribusi Daerah Kota Administrasi Jakarta Pusat Tahun 2014-2016, maka peneliti memberikan saran-saran sebagai berikut:

1. Sebaiknya Suku Badan Pajak dan Retribusi Daerah (BPRD) Provinsi DKI Jakarta terus melakukan perkenalan atau sosialisasi mengenai Online System Pajak Daerah kepada masyarakat, terutama Wajib Pajak yang bersangkutan. Hal yang harus disosialisasikan adalah mengenai cara atau tahapan dalam melakukan pembayaran pajak mereka melalui Online System tersebut

2. Pemerintah harusnya tidak menetapkan target yang terlalu tinggi setiap tahunnya, dikarenakan penerimaan yang diterima melalui sistem online tidak setiap tahunnya mengalami kenaikan yang begitu tinggi.

3. Pemerintah harus lebih tegas dalam memberikan sanksi kepada Wajib Pajak yang tidak patuh dalam melaporkan ataupun tidak membayarkan tagihan pajaknya. Dengan cara tersebut mungkin Wajib Pajak akan jera dan mulai patuh dalam melaporkan dan membayarkan pajaknya.

\subsection{Keterbatasan Penelitian}

Dalam penelitian ini, peneliti tentu mengalami keterbatasan yang menghambat peneliti dalam mengolah hasil penelitian. Adapun keterbatasan dalam penelitian ini adalah kurang tersedianya banyak 
waktu dalam melakukan penelitian ini, sehingga peneliti hanya melakukan penelitian pada satu wilayah saja, yaitu wilayah Jakarta Pusat.

\section{DAFTAR REFERENSI}

Dotulong, Garry A.G, David P. E. Saerang, dan Agus T. Poputra. 2014. Analisis Potensi Penerimaan dan Efektivitas Pajak Restoran di Kabupaten Minahasa Utara. Jurnal Berkala Ilmiah Efisiensi Vol. 14 No. 2 Mei 2014. Fakultas Ekonomi dan Bisnis, Universitas Sam Ratulangi Manado.

Hartati, Neneng. 2015. Pengantar Perpajakan. Bandung: Pustaka Setia.

Leliya, dan Fifi Afiyah. 2016. Efektivitas Sistem Pembayaran Pajak Daerah Online Dalam Peningkatan Pendapatan Daerah Kota Cirebon. Jurnal AL-Mustashfa Vol.4 No.2 Tahun 2016. Fakultas Syari'ah dan Ekonomi Islam IAIN Syekh Nurjati Cirebon.

Ling Zhang dan Wei. 2014. Research on Economic Grpeth and Tax Revenue with Environmental Dynamism Introduced Into. Jurnal Soft Science, Vol. 9. School Business and Administration, Human University.

Lumentah, Yulia Priskila. 2013. Analisis Penerapan Sistem Pemungutan Pajak Hiburan Di Kota Manado. Jurnal EMBA Vol.1 No.3 September 2013. Fakultas Ekonomi dan Bisnis, Jurusan Akuntansi Universitas Sam Ratulangi Manado.

Mardiasmo. 2016. Perpajakan Edisi Terbaru 2016. Yogyakarta: Andi.

Moldovan, Octavian. 2016. Local Revenue Mobilization in Romania. European Financial and Accounting Journal, 2016, vol.11, no. 3, pp. 107-124. Babeș-Bolyai University, Public Administration and Management Department.

Peraturan Daerah Nomor 03 Tahun 2015 Tentang Pajak Hiburan.

Peraturan Daerah Nomor 11 Tahun 2011 Tentang Pajak

Restoran.

Peraturan Gubernur Nomor 224 Tahun 2012 Tentang Pembayaran Dan Pelaporan Transaksi Usaha

Pajak Hotel, Pajak Restoran, Pajak Hiburan Dan Pajak Parkir Melalui Online System.

Purbosari, Hendrini. 2015. Pengaruh Penerapan Online System Terhadap Penerimaan Pajak Restoran Pada Suku Dinas Pelayanan Pajak Jakarta Timur. Skripsi. Jakarta: Sekolah Tinggi Ilmu Ekonomi Indonesia.

Putri, Roro Bella Ayu Wandani Prasetio, Srikandi Kumadji, Agung Darono. 2014. Analisis Penerimaan Pajak Hotel, Pajak Restoran, Pajak Hiburan Sebagai Sumber Pendapatan Asli Daerah Kota Malang. Jurnal Perpajakan Vol. 3 No. 1 Desember 2014. Fakultas Ilmu Administrasi, Universitas Brawijaya.

Samudra, A. A. 2015. Perpajakan di Indonesia: Keuangan, Pajak dan Retribusi Daerah. Jakarta: Rajagrafindo Persada.

Sumarsan, Thomas. 2010. Perpajakan Indonesia: Pedoman Perpajakan yang Lengkap Berdasarkan Undang-Undang Terbaru. Jakarta: Indeks.

Suryathika. 2016. Efektivitas Pemungutan Pajak Hiburan Sebagai Sumber Pendapatan Asli Daerah (PAD) Di DKI Jakarta. Skripsi. Jakarta: Sekolah Tinggi Ilmu Ekonomi Indonesia.

Undang-Undang Republik Indonesia Nomor 28 Tahun 2009 tentang Pajak Daerah dan Retribusi Daerah.

Walasik, Artur. 2015. The Propensity to Tax Competition: The Case of Implementation Local Tax Policy by Polish Local Governments. Eurasian Journal of Economics and Finance, 3(1),

2015, 28-37. University of Economics in Katowice, Poland.

Widiasari, Anita Ayu. 2016. Analisis Efektivitas dan Kontribusi Penerimaan Pajak Hotel dan Pajak 
Restoran terhadap Penerimaan PAD DKI Jakarta Tahun 2012-2015 (Kota Administrasi Jakarta Pusat). Skripsi. Jakarta: Sekolah Tinggi Ilmu Ekonomi Indonesia.

Winata, Doni, Abdul Wachid, dan Alfi Haris Wanto. 2015. Pelaksanaan Pemungutan Pajak Hiburan Secara Online Sebagai Upaya Meningkatkan Pendapatan Asli Daerah. Jurnal Administrasi Publik (JAP), Vol. 3, No. 1. Fakultas Ilmu Administrasi, Universitas Brawijaya, Malang.

Artikel dan lain-lain:

http://bprd.jakarta.go.id/pajak-restoran/

http://bprd.jakarta.go.id/pajak-online-masuk-direvisi-perda-pajak-tangsel/

https://zulkiflisasaja.wordpress.com/2014/04/15/pajak-hiburan/

http://accounting-media.blogspot.co.id/2014/06/data-primer-dan-data-sekunder.html

https://news.detik.com/advertorial-news-block/2764982/mudah-mengelola-keuangan-dengan-

cash-

management-system-bri 
